\title{
Elżbieta Woźnicka
}

ORCID 0000-0002-6505-1058

\section{DYDAKTYKA BIOGRAFICZNA W UJECCIU OLGI CZERNIAWSKIEJ}

\begin{abstract}
Słowa kluczowe: biografia, autobiografia, badania biograficzne, dydaktyka biograficzna, uczący się dorosły.

Streszczenie: Prezentowany artykuł jest próbą opisania dydaktyki biograficznej Olgi Czerniawskiej w oparciu o Jej dorobek naukowy oraz doświadczenie badawcze. Profesor Olga Czerniawska była prekursorką badań biograficznych w polskiej andragogice i gerontologii, a tym samym i dydaktyki biograficznej. W ostatnich latach swojej aktywności naukowej dużo miejsca i uwagi poświęciła badaniom biograficznym oraz wykorzystaniu w oświacie dorosłych dydaktyki biograficznej. Biografię i badanie biografii uczyniła przedmiotem swoich dociekań naukowych. Swoje doświadczenia badawcze Olga Czerniawska oparła na międzynarodowych badaniach biograficznych, które również są elementem niniejszego artykułu.
\end{abstract}

\section{Wprowadzenie}

Olgę Czerniawską należy zaliczyć do pionierów poszukiwań badawczych nad paradygmatem biograficzności w polskiej pedagogice, a w szczególności w oświacie dorosłych. W swojej pracy naukowej zajmowała się przedstawieniem roli biografii człowieka dorosłego w teorii, refleksji naukowej oraz praktyce, jej interpretacji i reinterpretacji jako sposobu poznania dorosłych i samopoznania jednostki. Wychowanie dorosłych postrzegała $\mathrm{O}$. Czerniawska jako proces poznania podmiotowego: upodmiotowienie edukacji dorosłych dokonuje się przez upodmiotowienie biografii człowieka dorosłego. Olga Czerniawska wyraźnie doceniała w swoich pracach takie podejście: Biograficzny nurt w edukacji dużo uwagi poświęca doświadczeniu. Człowiek staje się osoba nie tylko przez udział w życiu (doświadczenie), ale przede wszystkim przez rozumienie sensu życia. Dorosty kształtuje sie przez refleksję nad wtasnym życiem. Edukacja pojmowana jako proces stawania się soba musi wspierać dorosłego $w$ tej reinterpretacji życia, własnych doznań, kryzysów, frustracji i sukcesów (Czerniawska, 1995, s. 33). Refleksja Czerniawskiej 
nad biograficznością w edukacji dorosłych uwidacznia się w odwoływaniu się do koncepcji życia codziennego, koncepcji kształcenia incydentalnego, a więc też w rodzinie i w innych codziennych interakcjach. Olga Czerniawska przybliżała czytelnikom różne szkoły badań biograficznych: badania C. Houle'a nad uczącymi się dorosłymi, badania D.C. Kimmela (badania doświadczeń życiowych dorosłych - indywidualne projekty uczenia się dorosłych), badania Mezirova. Ważnym punktem odniesienia były dla Czerniawskiej badania G. Pineau (szkoła kanadyjska), P. Dominicé i jego ucznia M. Fingera (szkoła szwajcarska). Wiele przemyśleń dostarczyły autorce włoskie badania F. Susi, M. Lichtnera, F. Ferrarottiego czy wreszcie E. Gelpiego. Opierała się również na niemieckiej szkole badań nad historią życia, reprezentowanej przez H. Siberta i F. Schutza.

Biografia edukacyjna w ujęciu Olgi Czerniawskiej nie jest życiorysem. Opowiadający czy piszący przedstawia swoje życie w aspekcie wydarzeń edukacyjnych. Edukacja jest tu rozumiana szeroko jako proces spontaniczny i celowy, obejmujący socjalizację i wychowanie. Czerniawska zapoczątkowała w andragogice dyskurs nad badaniami biograficznymi, uczeniem się z własnej biografii, a także dydaktyką biograficzną.

\section{Dydaktyka dorosłych a dydaktyka biograficzna}

Dydaktyka jako subdyscyplina pedagogiki od dawna dysponuje własnymi metodami i zasadami kształcenia. W andragogice rozwój dydaktyki dorosłych następował od lat 50.-60. XX wieku (Urbańczyk, 1965; Thorndike, 1951). Dydaktyka dorosłych zrodziła się głównie z potrzeby rozwoju szkolnictwa formalnego dla dorosłych. Wypracowano zasady i metody różniące się od metod nauczania dzieci i młodzieży. Wraz z rozwojem andragogiki, pojawieniem się nowych trendów w edukacji dorosłych, rozwojem szkolnictwa pozaformalnego oraz edukacji incydentalnej badacze zajmujący się dydaktyką dorosłych doskonalili swoje metody i podejście do nauczania (Półturzycki 1991, 2002; Malewski 2001; Przybylska 2004). Następował rozwój badań jakościowych. Można uznać, że dydaktyka dorosłych stała się nowym obszarem zainteresowań andragogicznych i gerontologicznych, chociaż wśród wielu naukowców spotkała się i nadal spotyka ze sceptycznym przyjęciem, budzi liczne kontrowersje, rodzi pytania o efektywność badań biograficznych oraz obiektywność pozyskiwanych danych. Dydaktyka biograficzna obejmuje dzisiaj zagadnienia biograficznego uczenia się, stosowana może być również jako metoda prowadzenia zajęć z uczącymi się dorosłymi, a także seniorami. Chociaż zalicza się do młodych metod dydaktycznych, jest dość intensywnie eksplorowana przez andrologów i gerontologów.

Termin „dydaktyka biograficzna” wprowadzony został do andragogiki przez Olgę Czerniawską w pracy Szkice z andragogiki i gerontologii (2007). Zdaniem Czerniawskiej dydaktyka biograficzna jest alternatywą wobec dydaktyki, którą znamy, wyznaczającej standardy polskiego systemu oświaty (Czerniawska, 2007, 
s. 51). Dydaktyka biograficzna Czerniawskiej nie jest sposobem uczenia się szkolnego, formalnego: to rodzaj edukacji wynikający z doświadczenia, przeżyć, doświadczeń biograficznych. Odnosi się do edukacji całożyciowej, koncepcji całożyciowego uczenia się. Zdaniem autorki dydaktyka biograficzna jest alternatywą wobec dydaktyki, którą znamy, wyznaczającej standardy polskiego systemu oświaty (tamże, s. 51). Olga Czerniawska uważa, że tego rodzaju dydaktyka wyraża współczesne tendencje w edukacji dorosłych, zawarte m.in. w raporcie Delorsa Edukacja: jest w niej ukryty skarb (1998). I nie jest to, jak pisze autorka, dydaktyka sensu stricto ogólna lub wybranego przedmiotu. Mamy do czynienia z dydaktyką w ujęciu Johna Deweya, tzn. akceptującą aktywność nauczania, jego rolę w poszukiwaniu dialogu, docieraniu do prawdy i ewaluacji procesu edukacyjnego, tzn. miękkim uczeniem się - uczeniem się przez życie i doświadczanie (tamże, s. 51). Od badań biograficznych do dydaktyki - tak Olga Czerniawska określiła proces konstruowania się dydaktyki biograficznej. Zamiennie używała określeń „dydaktyka autobiograficzna” i „dydaktyka biograficzna”, ale znacznie częściej tego drugiego, które jest tożsame z autobiografią. Czasami określała je mianem formacji (proces samouznania i formowania się człowieka). Wypracowany przez Czerniawską na drodze badań model dydaktyki biograficznej to nabywanie kompetencji miękkich, uczenie się całożyciowe, ukierunkowane na rozwój emocjonalny, refleksyjność, kreatywność jednostki. Edukacja, która jest ukierunkowana na podmiot, na stuchanie uczestników i wzajemne stuchanie siebie. Rozwija przez to empatię i prospołeczne postawy. Sprzyja tolerancji, ma funkcję terapeutyczna i kreatywna (Czerniawska, 2007, s. 105). Nie odnosi się zatem do uczenia się sformalizowanego, lecz do uczenia, które docenia kształcenie całożyciowe i incydentalne człowieka dorosłego.

\section{Doświadczenia międzynarodowe Olgi Czerniawskiej w uprawianiu dydaktyki biograficznej}

Dydaktyka biograficzna ukształtowała się na bazie badań biograficznych, którymi Olga Czerniawska zajmowała się od lat 80 . Już wtedy wskazywała na niezbędne warunki do prowadzenia badań biograficznych. Dydaktyka biograficzna w badaniach andragogicznych znalazła swoje miejsce dopiero w latach 90. Powstała w kilku ośrodkach, których działalność oraz dorobek naukowy Olga Czerniawska systematycznie przybliżała. Jednym z nich był i jest Uniwersytet w Genewie, tworzył go profesor Pierre Dominicé (1992), którego książka Historia życia jako proces edukacji stała się ważną pracą dla andragogów podejmujących badania biograficzne. W 1996 i 1998 Czerniawska brała udział w konferencjach we Włoszech i Szwajcarii zorganizowanych przez Dominicé, na których wygłosiła referaty: Rola wspomnień z dzieciństwa w badaniach biograficznych oraz Moja Europa. Konferencje te odbywały się pod patronatem Międzynarodowego Towarzystwa Badań Andragogicznych ESREA. Drugim ośrodkiem rozwoju dydaktyki 
biograficznej był Mediolan, gdzie działał profesor Duccio Demetrio, autor takiej pracy jak Micropedagogia (1992), akcentującej podmiotowy, subiektywny i zróżnicowany wymiar procesu edukacyjnego. Demetrio uważał, że ten kierunek badań łączy paradygmat fenomenologii, psychologii klinicznej, intelektualizmu i konstruktywizmu, ponieważ przedmiotem dociekań czyni zjawiska takie jak wydarzenia edukacyjne, przeżycia i doświadczenia. Zróżnicowanie zależności tych zjawisk wynika z historii życia i natury podmiotu, który jest jedyny i niepowtarzalny. Historia życia i nabywanej na jego przestrzeni edukacji są główną materią analiz. Ujawniają potencjał jednostek, ich kreatywność i samodzielność intelektualną. Owa kreatywność staje się zaraźliwa. Uczy rozumieć siebie, innych i świat. Autobiografia przedstawia „,przestrzeń życiową” (Czerniawska, 2007, s. 52). Z Demetriem Czerniawska pierwszy raz spotkała się w 1979 roku we Frascati na konferencji z zakresu oświaty dorosłych, która odbywała się w CEDE w Villa Falconieri pod Rzymem. Przez wiele lat Czerniawska prenumerowała czasopismo Adultita, wydawane w Mediolanie pod redakcją Demetria, poświęcone edukacji dorosłych, a szczególnie preferowanym przez Demetria badaniom biograficznym, zwłaszcza w ujęciu fenomenologicznym i hermeneutycznym. Zajmowało się też andragogiką i pedagogiką międzykulturową. Staraniem Czerniawskiej w Polsce zostały wydane 3 książki Demetria. Pierwsza z nich, Zabawa na tle życia - gra autobiograficzna w edukacji dorostych (Kraków 1999), świetnie wpisuje się w dydaktykę biograficzną. Zawiera grę planszową składającą się z obrazków. W oparciu o tę grę i zaproponowane przez autora obrazki opowiada się historię życia. Ponadto książka zawiera propozycje warsztatów biograficznych. Drugą pracą była Autobiografia: terapeutyczny wymiar pisania o sobie, książka sprowadzona z Włoch za pośrednictwem Laury Formenti (współpracownicy Demetria), a trzecią Pedagogika pamięci, która dotarła do Czerniawskiej z pomocą polskiej emigrantki z Florencji. Do polskiego wydania tej książki profesor Czerniawska napisała przedmowę, którą tworzyła z uczuciem wzruszenia, niedowierzania i radości (Demetrio, 2009, s. 7). Poleca w niej książkę czytelnikom, szczególnie tym, którzy wybierają metodę badań biograficznych czy dydaktykę biograficzną. Książka składa się z krótkich rozdziałów, w których autor zastanawia się nad językiem pamięci, wspomnieniami z podróży, znaczeniem czasu, doświadczeń, rolą spotkanych osób. Zawiera przemyślenia Demetria związane z analizą wspomnień. Wiele rozważań autora może stać się przedmiotem warsztatów biograficznych z dorosłymi. Kolejny ośrodek rozwoju dydaktyki biograficznej to Bohum w Niemczech, gdzie działali profesorowie W. Mader i P. Alheit. Pisali oni o myśleniu biograficznym. Trzeba również wymienić klasyka badań biograficznych, którego Olga Czerniawska szczególnie ceniła, kanadyjsko-francuskiego badacza Gastona Pineau z Toronto, który uważał, że autobiografia prowadzi do autoedukacji. Na koniec wypada wspomnieć o ośrodku w Nantes, miejscu pracy profesor Martine Lani-Bayle, z którą Olga Czerniawska wydała publikacje oraz prowadziła międzynarodowy projekt badawczy pt. Wydarzenia osobiste i globalne. W badaniach M. Lani-Bayle ważną 
rolę odgrywał wątek genealogii rodziny, przekazu rodzinnego, szkoły. Dociekania profesor krążyły wokół tego, co się pamięta i tego, co się wypiera z pamięci. Ważnym ośrodkiem badań biograficznych stał się też ośrodek w Łodzi, stworzony przez profesor Czerniawską na Uniwersytecie Łódzkim: jako kierownik Katedry Teorii Wychowania rozpoczęła badania nad bigamicznością, organizowała konferencje poświęcone problematyce badań biograficznych. Dzisiaj profesor Elżbieta Kowalska-Dubas, kierownik Katedry Andragogiki i Gerontologii Wydziału Nauk o Wychowaniu UŁ, wraz z zespołem kontynuuje i rozwija badania biograficzne oraz dydaktykę biograficzną.

Dzięki kontaktom O. Czerniawskiej z andragogami z Europy Zachodniej oraz Kanady przybliżono polskiemu środowisku naukowemu zagraniczne koncepcje i ujęcie badań biograficznych.

\section{Od badań biograficznych Olgi Czerniawskiej do dydaktyki biograficznej}

Edukacja dorosłych oparta o badania biograficzne może być podstawą do poznania siebie, pomóc $\mathrm{w}$ tworzeniu własnej tożsamości, dokonywaniu bilansu życia, rozumieniu siebie, swojej epoki, porządkowaniu wspomnień, ocenianiu i wartościowaniu wydarzeń kształtujących nasze życie. Paradygmatem w badaniach biograficznych jest dorosłość jako zjawisko złożone, tworzone w trakcie życia i przez życie kształtowane. Edukacja dorosłych w ujęciu Olgi Czerniawskiej skupia się na złożoności tych procesów, na trajektorii biograficznej. Dorosły w procesie edukacji, uczenia się nie otrzymuje wiedzy, lecz ją współtworzy, uczestniczy w jej powstawaniu. Olga Czerniawska określa to uczestnictwo jako autobiograficzne, uwzględniając subiektywność, autonomię i potrzeby dorostego, jego trajektorii życiowych i uczenie się wyrażania siebie (Czerniawska, 2007, s. 54). Dydaktyka biograficzna wg Czerniawskiej czyni z dorosłego edukatora twórcę siebie samego, zachęca do samokształcenia i samowychowania. Poszczególne etapy dydaktyki biograficznej pozwalają na poznanie samego siebie, jak pisze O. Czerniawska: swojej wychowalności. Podstawą do uprawiania dydaktyki biograficznej wg Olgi Czerniawskiej są badania biograficzne. Uczą one rozmawiać i słuchać, rozumieć siebie. Czerniawska upowszechnia włoską szkołę dydaktyki biograficznej (D. Demetrio, L. Formenti). Za Formenti podaje kilka kroków, faz dydaktyki biograficznej pozwalających poznać siebie. Pierwszym krokiem (I faza) jest rozpoznanie własnej biografii, wydobycie z niej specyficznych etapów. Drugim krokiem (II fazą) jest odtworzenie biografii: przypomnienie sobie różnych konkretnych sytuacji z naszego życia. Faza trzecia to opracowanie historii życia, analiza własnych wydarzeń biograficznych. Czerniawska, czyniąc badania biograficzne podstawą dydaktyki biograficznej, odwołuje się do koncepcji metafory badania biografii edukacyjnej P. Dominicé (2006), który w procesie kształcenia studentów wykorzystywał analizy ich własnych biografii edukacyjnych. W procesie tym studenci występują w podwójnej roli: badaczy i osób badanych. Student poszukuje rozwiązania problemu przez pryzmat własnej biografii edukacyjnej. 
Dydaktyka biograficzna może opierać się na założeniu, że w życiu każdego z nas nadchodzi moment, w którym rodzi się przemożna chęć opowiadania o swoim życiu w inny niż zazwyczaj sposób. D. Demetrio, dzięki któremu Olga Czerniawska zainteresowała się pisaniem autobiografii, szczególnie poszukiwaniem metod gromadzenia biografii, uważa, że chęć opowiadania o sobie towarzyszy nam od setek lat, prawdopodobnie począwszy od chwili, w której pisanie jako akt twórczy przybrało formę historii o życiu, opowiadanej w pierwszej osobie, z zamiarem ocalenia od zapomnienia określonych przeżyć i doznań. Rodząca się chęć snucia opowieści o sobie częstokroć pozostaje niezaspokojona, nie wszyscy są bowiem zdolni do nadania jej epickiego kształtu. Jednak odczuwana potrzeba, zależnie od okoliczności, bywa koniecznością, obowiązkiem czy wręcz nakazem, ale i prawem jednocześnie. I chociaż w miarę upływu czasu może tracić na znaczeniu, przez całe życie jest obecna. Pisanie biografii nie polega tylko na byciu sam na sam ze sobą, przywoływaniu wspomnień, lecz także na przywoływaniu starych wspomnień w rozmowie z innymi. Demetrio nazywa to myślą biograficzną: Myśl biograficzna to mnogość nagromadzonych w ciagu całego życia wspomnień. Ta zrodzona niespodziewanie forma rozmyślań o własnym istnieniu towarzyszy człowiekowi zazwyczaj do końca życia, jej sekretna stale obecność zachęca do rozważań i medytacji, zaś przywoływanie wspomnień stać się może sensem i nadrzędna wartościa (Demetrio, 2000, s. 10). Wydobycie tej myśli autobiograficznej - rozumiane nie tylko jako dotarcie do wspomnień, lecz także jako stan ducha, osobliwy i dość rzadki (uważany niekiedy za swoisty rodzaj łaski) - dla Czerniawskiej było elementem dydaktyki biograficznej. Omawiana myśl staje się integralną częścią sfery intelektualnych doświadczeń jednostki dopiero wówczas, gdy przywoływanie przyszłości przybiera postać usystematyzowanego (o ile to możliwe, codziennego) zabiegu, a snujący rozważania filozoficzne dorosły jest w stanie odpowiedzieć na pytanie: kim jestem? Kim byłem? Zdaniem O. Czerniawskiej historie życia mogą być prezentowane poprzez pamiętniki, dzienniki, listy, treści przeprowadzonych wywiadów. Kluczowe dla zrozumienia dydaktyki biograficznej jest umiejętne potraktowanie narratora - dorosłego. Dydaktykę biograficzną O. Czerniawska odnosiła do pracy z człowiekiem dorosłym, na którego należy spojrzeć nie jak na uczącego się dorosłego w edukacji formalnej, lecz jak na jednostkę autonomiczną, zdolną do samodzielnego myślenia, organizowania swojej edukacji, świadomą znaczenia swoich przeżyć i doświadczeń. Badania biograficzne opierają się na założeniu, że edukacja jest procesem całożyciowym. Respondent odbywa wędrówkę w głąb siebie. W dydaktyce biograficznej O. Czerniawska odwołuje się do konstruktywizmu: dydaktyka biograficzna ma pokazać człowiekowi, jak żyć, nauczyć go budowania tożsamości, rozumienia siebie, rozumienia epoki, w której żyje, wykorzystywania własnych doświadczeń życiowych, dokonywania bilansu życiowego. Przedmiotem dydaktyki biograficznej wg O. Czerniawskiej może być całożyciowe uczenie się człowieka dorosłego. Autorka postrzega uczącego się jako bohatera historii, którą on sam opowiada i analizuje jej przebieg. Dorosły uczący się zdolny jest poddać swoją biografię refleksji i wyciągnąć z niej wnioski. 
Edukacyjny wymiar dydaktyki biograficznej Olgi Czerniawskiej oscyluje wokół upatrywania w człowieku zdolności do harmonijnego rozwoju. Opiera się na przekonaniu, że człowiek dorosły jest zdolny do świadomego i aktywnego, konstruktywnego wpływania na swoje życie, do planowania przyszłości i uczenia się z własnej biografii. O. Czerniawska zwraca uwagę na edukacyjne znaczenie sytuacji życiowych: z codziennych zdarzeń, relacji międzyludzkich można czerpać nauki.

Według Ewy Skibińskiej kategoria codzienności u O. Czerniawskiej jest źródłem doświadczeń, a samo doświadczenie uznane zostaje za odgrywające podstawową rolę w uczeniu się. Jak pisze Skibińska analizując dydaktykę biograficzną Olgi Czerniawskiej, odnoszącą się do edukacji pozaformalnej i incydentalnej, O. Czerniawska nie neguje znaczenia wiedzy zdobywanej w sposób tradycyjny, sformalizowany, zinstytucjonalizowany, potwierdzanej przez kolejne dyplomy $i$ świadectwa, ale uznaje ja za niewystarczająca. Podkreśla wartość zdobywanych samodzielnie, $w$ toku życia szerokich kompetencji. Jej zdaniem człowiek ma świadomość wptywania codzienności na jego proces uczenia się, jednak na ogót nie poddaje go refleksji, stąd sposób, w jaki uczenie się człowieka dokonuje się w jego środowisku życia, można poznać dopiero poprzez narracje autobiograficzne (Skibińska, 2009, s. 58).

Olga Czerniawska zdaje sobie sprawę z zawodności pamięci w badaniach biograficznych. Używa określenia wyspy pamięci: to zapamiętane zdarzenia i doznania, które człowiek przywołuje, budując historię swojego życia. Nie wszystko jednak człowiek chce wydobyć z pamięci ze względu na towarzyszące nieraz wspomnieniom trudne, często wręcz traumatyczne doznania. Taka podróż autobiograficzna jest trudna, dtuga i skomplikowana. Trzeba przejść przez owe wyspy pamięci, przez emocje, przyznać się, że się nie wszystko pamięta. Autobiografia jest odkryciem, przyczynia się do rozwoju (Czerniawska, 2007, s. 121). Poza pamięcią ważnym elementem dydaktyki biograficznej jest czas. Ludzkie życie Czerniawska ukazuje w kontekście czasu historycznego. Czas, w którym tworzy się historia konkretnego człowieka, jest nierozerwalnie związany z czasem historycznym. Czas ma wymiar indywidualny, ale i pokoleniowy. Wydarzenia globalne, ulokowane w konkretnej rzeczywistości społeczno-kulturowej, historycznej, dla opowiadającego, tworzącego swoją historię stają się elementem czasu osobistego i odwrotnie: jednostkowe historie życiowe składają się na obraz pokolenia. Czas historyczny jest czasem osobistym, jednostkowym, czasem ego, czasem życia. Świadkowie tych samych wydarzeń historycznych relacjonują je inaczej (2007, s. 119).

\section{Cele dydaktyki biograficznej w ujęciu Olgi Czerniawskiej}

Dydaktyka biograficzna może sprawić, że nadanie epickiego charakteru opowiadaniu o życiu i tworzenie retrospektywnego zapisu przeżyć stworzą nowy 
wymiar ludzkiej egzystencji. Istotę tak rozumianej dydaktyki biograficznej stanowią pytania, która mają pomóc w odwołaniu się do wspomnień. $Z$ dydaktyki biograficznej Olgi Czerniawskiej nauczyć się możemy przede wszystkim wrażliwości, otwarcia na drugiego człowieka, jego przeżycia, doświadczenia. Wskazówki pozwalające na uprawianie rozwojowej dydaktyki biograficznej O. Czerniawska zawarła w kilku punktach:

- uczącego się dorosłego biorącego udział w warsztatach dydaktyki biograficznej należy obdarzyć zaufaniem, uznać kompetencje podmiotu do autonomicznego decydowania o sobie;

- należy kłaść nacisk na rozpoznawanie procesów uczenia się i uwikłań biograficznych, a przede wszystkim uwarunkowań wynikających z przeżyć i ich wpływu na biografię;

- muszą zaistnieć wspierające połączenia między badaniami a kształceniem, między procesami, postawą, doświadczeniem i przeżyciami a uczeniem się, ważna jest ich współzależność;

- uwzględnia się autonomię, subiektywność, potrzeby człowieka dorosłego;

- metoda prowadzi przez spontaniczność, narrację wypowiedzi z życia;

- dorosły uczy się przedstawiać swoje potrzeby, kształtuje siebie i otoczenie;

- dokonuje oceny kursu oraz wyraża swoje oczekiwania;

- badania są procesem samopoznania i formacji (2007, s. 55).

Cel dydaktyki biograficznej w ujęciu Olgi Czerniawskiej to głównie zachęcenie dorosłego do procesu samowychowania, samokształcenia, zmiany swego zachowania, bardziej obiektywnego i krytycznego postrzegania samego siebie. Istotną rolę odgrywa tu umiejętne spożytkowanie doświadczenia dorosłych z wykorzystaniem aktywnych metod bazujących na doświadczeniach, takich jak burza mózgów, indywidualny przypadek, warsztaty biograficzne. Dydaktyka biograficzna, a szczególnie jej autobiograficzny wymiar, wymaga umiejętności obserwowania samego siebie. W warsztatach biograficznych trzeba przygotować uczestnika na przyjęcie pozycji obserwatora swojego życia. Posługuje się on słowem pisanym lub mówionym (nagraniem): trzeba ocenić ten wybór z pozycji możliwie obiektywnej. Udział w warsztatach polega na autobiograficznym uporządkowaniu przedstawienia swojego życia. Wymaga uporządkowania faktów i pamięci, opowiadania, opisu. Autobiografia dotyczy wrażliwego, delikatnego obszaru - emocji, świadomości, ukrytych obszarów naszej osobowości (intymności). Wymaga nie tylko wiedzy nabytej, lecz także doświadczenia życiowego, w szerokim tego słowa znaczeniu. Wkracza w to, o czym chcemy zapomnieć, czasem już zapomnieliśmy, wyeliminowaliśmy z pamięci. Jeśli chcemy w petni sprostać dydaktyce autobiograficznej, stajemy się poddani trudnym regutom zrekonstruowania autobiografii edukacyjnej, dróg edukacyjnych. Należy poddać w tym przypadku analizie własne działania, ocenić oddziaływania innych osób i instytucji na nas. Jednostka dokonuje heurezy, poszukuje sytuacji, faktów w swoim życiu, które wptynęty na jej osobowość (Czerniawska, 2007, s. 57). 
Uczenie się z własnej biografii to uczenie się przez działanie. Olga Czerniawska uważała, że dydaktyka biograficzna powinna polegać na zajęciach z grupą osób od 6 do 12, które chcą uczestniczyć w warsztatach biograficznych (traktowanych przez Czerniawską jako badania uczestniczące) i akceptują wszystkie zasady tego uczestnictwa. Zgodnie z koncepcją badaczki zajęcia takie mają kilka faz: pierwsza z nich polega na wysłuchiwaniu opowiadanych przez poszczególnych uczestników historii ich życia. Słuchacze wypowiadają się, ale w tych wypowiedziach nie ma oceny i krytyki innych. Są refleksje, analiza, ewentualnie pytania. Następnie grupa poszukuje wspólnych elementów opowieści, podobnych problemów, wydarzeń. Najczęściej warsztaty trwają 6 miesięcy. Uczestnicy spotykają się 2 razy w miesiącu, pomiędzy spotkaniami mają indywidualne zadania do wykonania. Warsztaty powinny wg O. Czerniawskiej obejmować 3 fazy: wstępną, właściwą (konstruktywną) i refleksyjną (wymiany myśli, swoistej ewaluacji). Faza wstępna uruchamia pamięć, porządkuje fakty. Uczestnik zaczyna pisać historię życia, tworzy ramy opowieści, opowiada o sobie. Można w tym celu wykorzystywać rodzinne fotografie, listy, książki itp., rysować mapę biograficzną. W trakcie zajęć uczestnicy wykonują zadania indywidualne, mogą pisać dziennik, obserwować swoje przeżycia, przygotowywać pytania. Według O. Czerniawskiej istnieją różne sposoby poszukiwania siebie, drogi dokonywania swojej przemiany: mogą temu posłużyć listy, pamiętniki, dzienniki. Główną metodą w dydaktyce biograficznej jest wywiad narracyjny. Uczy on prowadzenia rozmowy z innymi, uważnego słuchania i szacunku. Wywiad biograficzny, a następnie opracowanie biografii to narzędzia dydaktyki biograficznej: Spetniaja rolę podobna do roli archeologii, z elementów pamięci odtwarzaja całe obrazy, fragmenty przeszłości. [...] Powstaje obraz przeszłości, nasza biografia. W trakcie tych działań nie tylko porzadkuje się wspomnienia, pamięć, ale także je oczyszcza. Co pamiętać i jak pamiętać, co zapomnieć i dlaczego. Z pamięcia mamy dokonywać podobnych zabiegów, jak z procesem uczenia się. Uczyć się uczyć, ale i uczyć się oduczać. Wydaje się, że w tym oczyszczaniu pamięci tkwi najistotniejszy walor dydaktyki biograficznej. (Czerniawska, 2007, s. 66-67).

Olga Czerniawska w dydaktyce biograficznej odwołuje się do teorii środowiska niewidzialnego w pedagogice społecznej. Przedstawiane przez narratora środowisko, jego czasy pełnią taką funkcję. Dydaktyka biograficzna może przyczynić się do opisu środowiska, które kiedyś istniało - było domem rodzinnym, miasteczkiem, szkołą, stowarzyszeniem, rodziną narratora, jego sacrum i profanum (Czerniawska, 2007, s. 110). Wiedza na temat przemijającej przeszłości wzbogaca narratora, który przypomina sobie przeszłość, prowadzącego wywiad i czytelnika wywiadu. Dydaktyka biograficzna O. Czerniawskiej oscyluje wokół trzech tematów: wspomnień narratora, ich porządkowania i analizy własnego życia. Badaczka wskazuje na szczególną rolę narratora. Sam wywiad stymuluje go, bo narrator musi się zastanowić, przypomnieć sobie przeszłość, uporządkować wspomnienia, zwerbalizować je, chcieć mówić, wyrażać pewne opinie, a to, co 
głośno powiedziane, staje się faktem, który można oceniać, analizować. Osoba słuchająca wypowiedzi musi odważyć się przeprowadzić wywiad, słuchać, zachęcać do wypowiedzi, pomagać narratorowi, szanować jego wspomnienia. Musi opanować swoje uczucia, być tylko aktywnym, życzliwym słuchaczem. Powstały w trakcie wywiadu materiał - historia życia, opowieści o wydarzeniach - zawiera w sobie pewne przesłanie o narratorze, o jego czasach i środowisku, o przeszłości i jej realiach.

\section{Przykłady zastosowania dydaktyki biograficznej przez Olgę Czerniawską}

Dydaktyka autobiograficzna może przyjąć formy bezpośrednie (autobiografii tematycznych ze szczególnym uwzględnieniem wydarzeń edukacyjnych, określonych przeżyć, np. dzieciństwa, emerytury, pracy zawodowej) bądź pośrednie: pisania na wybrany czy podany temat. Ten ostatni sposób ma na celu rozbudzenie lub pobudzenie aktywności twórczej. Obeznana z artykułami publikowanymi w czasopismach andragogicznych w językach włoskim i francuskim, Olga Czerniawska przybliżyła polskim czytelnikom opisywane tam badania realizowane $\mathrm{w}$ ramach dydaktyki biograficznej. Były to m.in. zajęcia na UTW z seniorami w Kanadzie, warsztaty z nauczycielami matematyki w Rzymie, seminaria w Noisy we Francji zorganizowane dla bezdomnych, seminaria kobiet pochodzących z Algierii, tworzenie wirtualnych grup biograficznych (Czerniawska, 2007; Czerniawska, 2001). Dydaktykę biograficzną uprawiała również O. Czerniawska na prowadzonych seminariach magisterskich i licencjackich. Prowadzone przez Nią seminaria miały najczęściej charakter monotematyczny, na przykład: Moje dzieciństwo, Pamięć szkoły, Pamięć dzieciństwa, Mój pierwszy dzień na emeryturze, Moje drogi edukacyjne, Wydarzenia osobiste i globalne itp. Jak pisała: Badania te stymuluja samopoznanie [...]. Do tego potrzebna jest rozbudzona świadomość poznania siebie, swoich korzeni, nauczenia się analizy własnej przeszłości, aby lepiej korzystać z teraźniejszości i współtworzyć przyszłość. Czas mija, ale można go zatrzymać przez powroty do niego pamięcia (Czerniawska, 1999, s. 167). Ponadto uważała, że dzięki tego rodzaju seminariom studenci nie tylko uczą się prowadzenia badań metodami jakościowymi, lecz także mają szansę zbliżyć się do respondentów, wypracowują inne spojrzenie na swojego rozmówcę. Jeżeli seminaria miały charakter wielotematyczny, zawsze metodą badań był indywidualny przepadek lub metoda biograficzna. Profesor Czerniawska podkreślała, że wyrażała zgodę na taką formułę seminarium: uczę się od studentów o ich instytucjach, o ich świecie (Czerniawska, 2007, s. 64). Projekt badawczy O. Czerniawskiej o charakterze dydaktyki biograficznej, zatytułowany Ludzie starsi jako sity społeczne, ukazywał ludzi starszych jako planujących swoje życie, starość, radzenie sobie z samotnością, pobyt w domu pomocy społecznej, pracę na rzecz innych (Czerniawska, 2002). Inny projekt to Podróż i jej wymiar edukacyjny, duchowy, osobisty, zawodowy (różne wymiary podróży) (Czerniawska, Juraś-Krawczyk, 2001; Czerniawska 
2003). Polsko-francuskie Wydarzenia osobiste i globalne były najistotniejszym w pracy naukowej Czerniawskiej badaniem ukazującym zastosowanie dydaktyki biograficznej. Jego genezy należy upatrywać w międzynarodowych kontaktach O. Czerniawskiej z prof. Pierre'em Dominicé, prof. Martine Lani-Bayle z Nantes. Projekt powstał w 2003 roku, realizowany był przez kilka kolejnych lat i zakonczył się międzynarodową konferencją w 2007 roku w Akademii Humanistyczno-Ekonomicznej w Łodzi. Etapy badań referowane były również na 2 międzynarodowych konferencjach w Nantes (w czerwcu i w październiku 2005 roku).

Dydaktyka biograficzna proponowana przez O. Czerniawską jest spójna z dydaktyką Duccia Demetria i dlatego może spełniać funkcję terapeutyczną, ale także naprawczą, poznawczą. Pozwala na zrozumienie swojej sytuacji zawodowej, społecznej, życiowej czy edukacyjnej. Zrozumienie swojej biedy, roli zawodowej, znalezienia się w sytuacji beznadziejnej stały się podstawą do zorganizowania warsztatów. Dydaktyka biograficzna wykorzystywana jest również w pracy z seniorami. Znajduje zastosowanie w kształceniu na odległość. Pisanie pamiętników może mieć też wartość w środowisku lokalnym.

\section{Zakończenie}

Olga Czerniawska buduje dydaktykę biograficzną wokół takich pojęć jak biografia, autobiografia, edukacja całożyciowa, czas, historia. W centrum zainteresowania pozostaje człowiek i jego biografia i indywidualność, zachęcenie go do przyjrzenia się własnym doświadczeniom życiowym, opowiedzenia i zrozumienia swojej historii. W dydaktyce biograficznej uprawianej przez O. Czerniawską najważniejszy jest proces poznania samego siebie. Wychowanie dorosłych z perspektywy dydaktyki biograficznej postrzegała O. Czerniawska jako proces poznania podmiotowego: upodmiotowienie edukacji dorosłych dokonuje się poprzez upodmiotowienie biografii człowieka dorosłego. Przyjrzenie się własnej drodze życiowej i edukacyjnej prowadzi go - z pomocą nauczyciela - do ukształtowania swojej tożsamości. Olga Czerniawska była wielką humanistką, stąd w Jej pracach uwypuklenie podmiotowości uczącego się dorosłego, jego autonomii i zdolności do samostanowienia. Dzięki profesor Oldze Czerniawskiej w polskiej andragogice coraz częściej stosowane są badania biograficzne i coraz bardziej ceni się ich edukacyjne przesłanie, funkcje, a także dydaktyczne możliwości.

\section{Bibliografia}

Czerniawska, O. (red.). (2011). Andragogiczny wymiar wydarzeń osobistych i globalnych w badaniach biograficznych. Łódź: Wydawnictwo Akademii Humanistyczno-Ekonomicznej w Łodzi:

Czerniawska, O. (1999). Badania biograficzne i ich rola w ksztatceniu andragogicznym. W: E. Solarczyk-Ambrozik, K. Przyszczypkowski (red.), Oświata Dorostych. Poznań - Torun. 
Czerniawska, O. (2001). Edukacyjne przesłanie kongresów AIUTA. Edukacja Dorostych, $n r 2$.

Czerniawska, O. (2002). Ludzie starsi jako sity społeczne. Łódź: Zeszyty Naukowe WSHE.

Czerniawska, O. (2007). Szkice z andragogiki i gerontologii. Łódź: Wydawnictwo Wyższej Szkoły Humanistyczno-Ekonomicznej w Łodzi.

Czerniawska, O. (1995). Pedagogika ugody i wyboru a edukacja dorosłych. Edukacja Dorostych, $n r 3$.

Czerniawska, O., Juraś-Krawczyk, B. (2001). Podróż jako projekt edukacyjny. Łódź: Wydawnictwo Wyższej Szkoły Humanistyczno-Ekonomicznej w Łodzi.

Delors, J. (1998). Edukacja jest w niej ukryty skarb. Warszawa: Wydawnictwo UNESCO.

Demetrio, D. (2000). Autobiografia. Terapeutyczny wymiar pisania o sobie. Kraków: Oficyna Wydawnicza Impuls.

Demetrio, D. (2009). Pedagogika pamięci. Łódź: Wydawnictwo Akademii Humanistyczno-Ekonomicznej w Łodzi.

Demetrio, D. (1999). Zabawa na tle życia - gra autobiograficzna w edukacji dorostych. Kraków: Wydawnictwo Impuls.

Malewski, M. (2001). Modele pracy edukacyjnej z ludźmi dorosłymi. W: E. Przybylska (red.), Andragogiczne wątki, poszukiwania, fascynacje. Toruń.

Półturzycki, J. (2002). Dydaktyka dla nauczycieli. Płock: Wydawnictwo Novum Płock.

Półturzycki, J. (1991). Dydaktyka dorostych. Warszawa: WSiP.

Przybylska, E. (red.). (2004). Dydaktyka i metodyka edukacji dorostych. Materiaty dydaktyczne do zajęć z teorii i praktyki. Warszawa.

Skibińska, E. (2009). Dydaktyka biograficzna: nowy obszar poznawczy andragogiki czy nowa utopia? Teraźniejszość - Człowiek - Edukacja, nr 2 (46).

Thorndike, E.L. (1951). Uczenie się dorostych. Warszawa.

Urbańczyk, F. (1956-1973). Dydaktyka dorostych. Ossolineum: Warszawa-Kraków.

\section{Biographical didactics according to Olga Czerniawska}

Keywords: biography, autobiography, biographical research, biographical didactics, adult learning.

Summary: The presented article is an attempt to describe the biographical didactics of Olga Czerniawska based on Her scientific achievements and research experience. Professor Olga Czerniawska was a precursor of biographical research in Polish andragogy and gerontology, and thus also in biographical didactics. In last years of her scientific activity, she devoted a lot of space and attention to biographical research and the use of biographical didactics in adult education. She made biography and the study of biographies the subject of her scientific research. Olga Czerniawska based her research experience on international biographical research, which is also an element of this article.

Dane do korespondencji:

\section{Dr Elżbieta Woźnicka}

Państwowa Uczelnia im. Stefana Batorego w Skierniewicach e_woznicka@wp.pl 